\title{
Perspectives and Challenges of the Kolis and Ramponkars societies in the Western Indian Coast.
}

\author{
Sarita Fernandes ${ }^{1}$
}

\section{Abstract}

A coast is a dynamic zone - accessible for a limited duration and dependent on the interplay of tides. Coastal zones are sensitive ecological habitats rich in resources and marine biodiversity. It has been a pivotal zone of cultural exchange, many of them resulting in the inception of coastal societies and cities. The building capacity and immense capability of a coast for strategy in protecting a sovereign state, a colonial power or a kingdom in the past has been a subject of historical and colonial maritime literature. Two and a half billion people $(40 \%$ of the global population) live within a hundred kilometres of the coastline (United Nations 2017). The linguistic diversity, traditional fishing methods like pole and line, spear fishing and shore seine alongside colonial history presents a magnum diversity of coastal societies in the urban and rural spectrum in India. The coastal zones of the intertidal and subtidal are nursery grounds for most of the predatory species of marine wildlife that are apex in the marine food web like sea turtles, sharks and dolphins whose reducing numbers have a direct impact on the health and functioning of the coast and ocean. Traditional or indigenous coastal societies have interplay between activities in the traditional law of the coastal commons and dynamic shifting land use with the sea. The study of livelihoods from such societies is recorded in colonial and post-independence literature which is limited only to the economic factor of fisheries. The Kolis in Maharashtra and Ramponkars in Goa are two distinct coastal societies that are very poorly documented in India. Neoliberalism has presented a combination of existing and modern options of livelihoods within the Koli and Ramponkar societies like large scale fisheries, tourism and trade. The Kolis and Ramponkars are engaged in small-scale and traditional methods of fishing and tourism. They presently find challenges in sustaining and striving to be resilient in the rising demand for the growth and

\footnotetext{
${ }^{1}$ Sarita Fernandes is a Research Associate, National Maritime Foundation. This paper was presented by the author during the webinar on Emerging India from Maritime Perspective to commemorate National Maritime Day on 05 April 2021. The Event was co-hosted by EJSSS along with UGC Centre for Maritime Studies, Pondicherry University.
} 
infrastructure requirements in large scale tourism, coastal industrialization, maritime trade and commercial fisheries. This paper explores the perspectives of indigeneity in the western coastal societies of the Kolis in Maharashtra and the Ramponkars in Goa and the rising challenges towards these concerns. It also offers discussions on mitigation and possible options.

Keywords: Coastal societies, indigenous, coastal commons, climate change, neoliberalism, culture, diversity.

\section{Introduction}

The paper will address the distinct perspectives, colonial accounts, present relevance and challenges of the Kolis in Maharashtra and Ramponkars in Goa. Colonial records of the East India Company in Bombay (now Mumbai) and the Portuguese Government in Goa, academic documentation alongside documented accounts using the participant observer approach (DeWant and DeWant, 2002) from field notes were used in the discussion and analysis of the paper.

Coastlines in general are highly productive for any country as they provide a global interconnectivity of goods and service ecosystems which is central to socio-cultural and economic development (Chime Youdon, 2020). The sea provided far easier opportunities for travel, exchange and cultural interconnectivity in earlier times (Linde Egberts, 2020). Coastal societies are diverse and have a large portion of their livelihoods directly related to foreshore activities like fisheries, tourism, trade and industry (Linde Egberts, 2020). Coastal zones have been defined through dynamic interactions by human beings inhabiting coastal areas and recording what occurs in their environments (Carola Hein, 2020). Adaptation to coastal hazards in the past occurred by abandonment and retreat from the coast due to the lack of technology, economic incentives and political will (Karl Nordstrom, 2016). However, it is now established that human beings are intrinsic to coastal systems and our activities include both eliminating and restoring coastal landforms and habitats (Marcha Johnson, 2016).

Prehistorically, the coast has provided human beings with habitat, food, trade routes and facilitated socio-economic networks. Before the Neolithic Revolution (hunting, fishing, and gathering to 
farming societies) socio-economic systems were dependent on the relative sea-level change, requiring migration according to the shifting direction of the coast (Jann Harff, 2019). Coastal communities and societies are historically interconnected with each other and are much more similar than inland societies in customs, way of life, methods of construction-architecture and heritage. (Linde Egberts, 2020). These communities also share a distinctive cultural relationship with the sea (Linde Egberts, 2020). Port cities were closer to each other by water than places that could only be reached by land. (Linde Egberts, 2020). The port city zones were looked upon as a dynamic and tangible aspect of urban life. In the historical and present times, mercantile and naval ports are nationally prestigious given their history, economic interconnectedness, exchange and trade between such cities (Linde Egberts, 2020).

Activities around a coast and sea vary in each country, depending on its unique national vision and circumstances adopted to reflect its own conception of a blue economy (World Bank, 2017).

The dynamic feature of a coastal zone coupled with the advent of neoliberalism has resulted in the cultural sketching (Isabel Altamirano-Jimènez, 2013) of the share of coastal commons among different demographics inhabiting a coastline. The activities thus, that coastal societies engage in vary with regard to economic gains, cultural interconnectivity, indigeneity and networking. The comparable functions of a coast as a commons for cultural exchange, trade, fisheries, migration and tourism show similarities in heritage and to some extent, comparisons in challenges of preservation and development of these zones (Linde Egberts, 2020). There is little awareness about the biocultural, socio-economic and diversity of the communities inhabiting the Indian coast. (Lisba Yesudas et al. 2019). Marine biodiversity and cultural diversity are deeply interwoven in such communities (Lisba Yesudas et al. 2019), that is often displayed through community craftsmanship, equipment branding and ornamental expression (Pranita Harad et al. 2019). There is growing awareness that scientific knowledge alone is inadequate for solving the emerging environmental crisis. (UNESCO, 2012). The interdependencies and complexities of climate change on coastlines demand a comprehensive approach, cutting through silos and political positions (Henk Ovinik, 2020). 


\section{Coastal societies of Maharashtra and Goa}

\section{Kolis of Mumbai (Maharashtra)}

Based on the archaeological excavations and morphological data available, it has been suggested that a major population of Maharashtra has been indigenous to the western Indian region for the last five millennia and much longer (L.S Sanghvi, 1977) ${ }^{2}$. An established tale maintains that before Bombay (now Mumbai) was a bustling colonial city of the East India Company, it was merely a fishing village of seven islands inhabited by the Kolis, a community known to be Mumbai's original inhabitants (Sheetal Chabbaria, 2018). A similar narrative of an isolated fishing village transitioning into a colonial coastal city exists for Karachi and Calcutta. The name 'Karachi' is said to have derived from a fisherwoman 'Mai Kolachi' and narrates a similar tale of fishers as original inhabitants of the coast (Arif Hasan, 2002).

There are about twenty-seven communities who identify themselves as Koli fishers in Maharashtra (Pranita Harad et al. 2019). They are further divided among villages based on their methods of inland and pelagic fishing. These settlements were previously found scattered in and around Mumbai, Thane and Raigad coasts, with coastal settlements in the Konkan region spread from Vasai-Virar up to Ratnagiri (Ghurye, 1696; Pranita et al. 2019). Symbolism of fish, waves, boats and stories based on the Koli daily interaction with the coast is prominent in rituals and cultural expression (Pranita Harad et al. 2019). A gender division of work distribution between fishermen and fisherwomen is well established and defined through these villages (Pranita et al. 2019).

Figure 1.1 Coastline of India

\footnotetext{
21 millennium (millennia: plural) is equal to 1000 years. The study by Dr. L.S Sanghvi was done on behalf of TATA Memorial hospital in 1977 using -- method.
} 


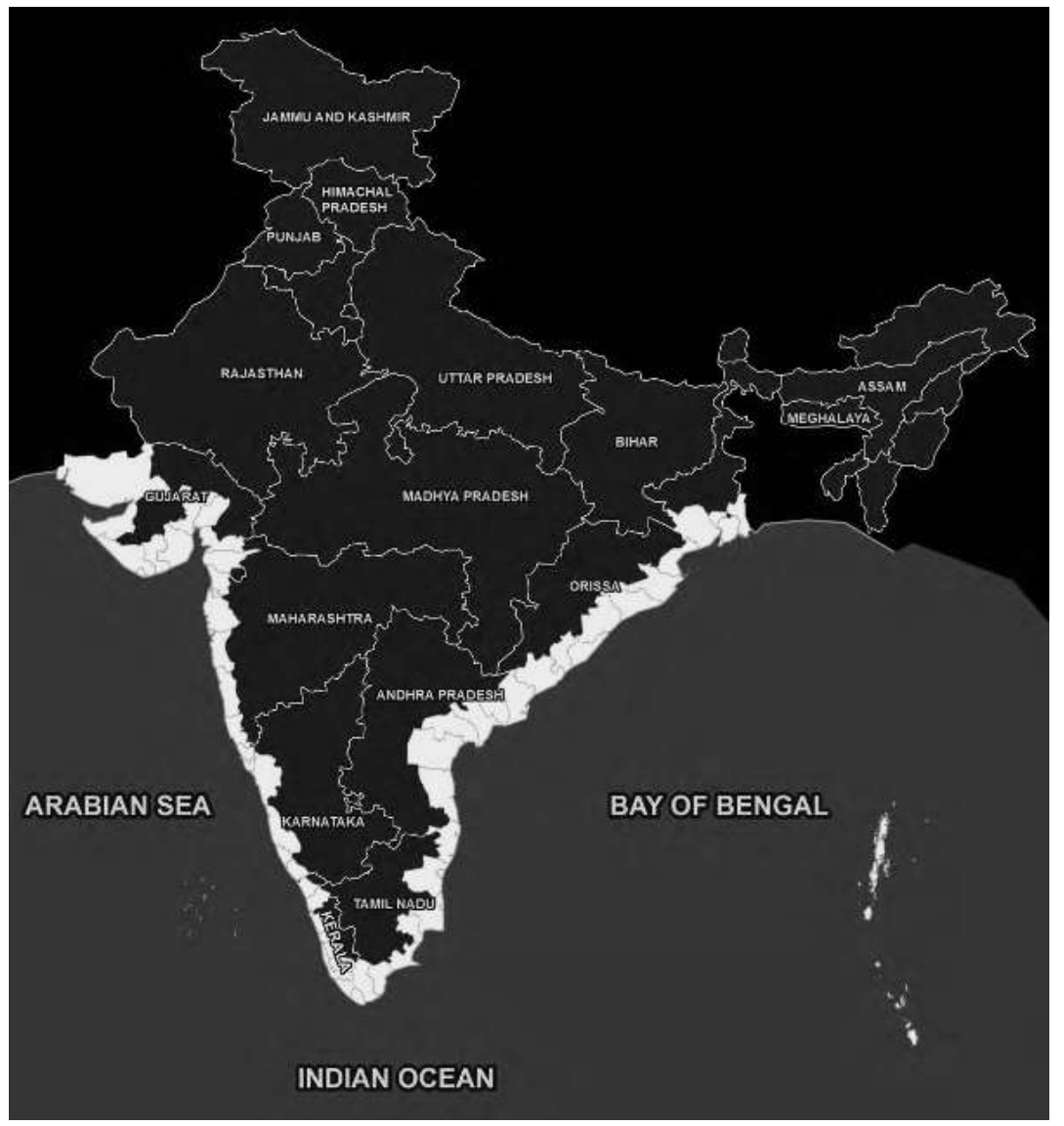

Source: Centre for Coastal Zone Management and Coastal Shelter Belt, 2017

The Koli community presents a clear approach in defining an identity based on indigeneity from the rest of the urban population in Mumbai (Punekar, 1959). The sustained effort in displaying the rural-urban essence is witnessed through policy demands and subsequent inclusions into planning policies which secure the coastal society's fishing villages also locally known as koliwadas. There is uniformity in the Koli villages or koliwadas across Mumbai in displaying their dependence and access to the sea through unique cultural beliefs and food (Punekar, 1959; Isabel AltamiranoJimènez, 2013).

Colonial Bombay's Portfolio Capitalism which depended on the flexibility and availability of local labour and capital formed the nexus of Bombay's (now Mumbai) economic course (Sheetal 
Chabbaria, 2018) ${ }^{3}$. The spatial re-ordering of the seven islands for maximising revenue led to the dispossessions through compensatory and coercive methods by the East India Company of the British Raj with local groups (Sheetal Chabbaria, 2018). Among the local groups who repeatedly renegotiated these compensations were the Kolis who initially were indistinguishable from the rest of the local population, but later managed to establish a customary-claimant indigenous status with the British (Sheetal Chabbaria, 2018). Koli representations and active roles in the spatial reordering of Bombay provided a legitimacy in describing the society as 'a local group of non-modern fishing peoples wilfully confined to coastal locations because of their nature based and primordial identity... who needed to be protected by granting them access to the sea'. (Shibani Roy, 1983; Sheetal Chabbaria, 2018)

The movement and displacement of inhabitants in Bombay (now Mumbai) was based on the employment and affordability in the rental markets, eliminating 'fishermen' who acquired specially allocated lands for their fishing villages (Sheetal Chabbaria, 2018). This made the Kolis an indigenous society in the 'rurban' nexus of the East India Company and later on the British Raj (Sheetal Chabbaria, 2018). ${ }^{4}$ The dynamism of these 'rurban' networks primarily supported the economics in establishing a colony in Bombay dominated by the East India Company. (Frank Perlin, 1983; Sheetal Chabbaria 2018) Political representation by the twentieth century structured an ambiguous pathway to the Kolis to include themselves as an established coastal society based on the customary claimant and cultural identity of the community's affinity and 'necessity of access' to the coast and sea (Sheetal Chabbaria, 2018).

\section{Goa}

The coastal society and cultural divisions in Goa was based on the Portuguese indo-colonial laws and class and caste hierarchy it instated for adequate governance of the colony (Paul Routledge, 2001). The goan society is cross cut by several factors based on language, gender, religion and

\footnotetext{
${ }^{3}$ Portfolio Capitalism refers to the sub-groups of merchants that reflected active participation in political discourse and commerce. The flexible pool of labour and local portfolio capitalists were central to the course of Bombay's colonial history. (Sanjay Subrahmanyam, C.A Bayly 1988)

${ }^{4}$ Rurban (Rural-urban) nexus - a term used by Historian Frank Perlin to describe trans-local spaces of early Eurasia where gradual shifts in population density formed a social continuum between urban and rural functions.
} 
caste (Paul Routledge, 2001). The popular cultural division of 'Goa Indica' (The Indian basis of Goan culture) and 'Goa Dourada' (Golden Goa) is a prominent colonial legacy of the Portuguese rule for almost four decades, whose influence of the latter is currently witnessed in the modern tourism narratives of the state (Paul Routledge, 2001). The Ramponkars, Dangar, Velips, Gauda, Kharvi and Kunbi were tribal groups whose primary occupation was agriculture, toddy tapping, craftsmaking, coconut grove cultivation and fishing (Ecoforum, 1995; Shirodkar et al.1993). These groups were dominantly part of the biocultural indigenous identity of the coastal societal construct in Goa (Ecoforum, 1995; Shirodkar et al.1993) as communities that were completely dependent on coastal resources for sustenance. The 'Ramponkars' a fisher community that translates as 'traditional beach fisherfolk' in Konkani, are an established society of indigenous fishers that uses the 'rampon' method of fishing based on time and tested skills and techniques that have been practiced for centuries in Goa (Somayaji and Coelho 2017).

The seafood gastronomy in Goa is an existing stalwart of this common dependence and multinodal use of the coast for sustenance. (Paul Routledge, 2001; Somayaji and Coelho, 2017) The 'fish-curry-rice' is a prominent example of the coastal staple and cultural symbol of food among all Goan societies irrespective of class and tribe. ${ }^{5}$ (Paul Routledge, 2001; Ecoforum 1995, Shirodkar et al. 1993 Somayaji and Coelho, 2017)

\section{Ramponkars of Goa}

Native goans used the shoreline, inland water bodies and coastal zones surrounding them for agriculture, traditional fishing, and low intensive recreational activities (Alvares, 1993; Antonio Mascarenhas, 1999). The Ramponkars were a largely patrilocal and endogamous coastal community that had colloquial customary rights to reside near the beach (Somayaji and Coelho, 2017). The community practices a labour distributive method of fishing based on the co-operative use of the coast and sea as a 'common resource'. This method is also called beach or shore seine fishing (Aaron Lobo, 2020). The use of the 'rampon' - a giant fishing net formed by joining several

\footnotetext{
${ }^{5}$ Fish curry rice is a cultural gastronomic symbol of the staple food in Goa that denotes the heritage and biodiverse products of coconuts (used in curry), rice from the paddy and khazan fields and fish from the shore and inland waterways of Goa.
} 
smaller nets of the fishers involved in the exercise - would be casted into the sea and pulled back shoreward by a group of 40-50 men (D'cruz and Raikar, 2004). The ownership of smaller nets leading to the giant 'rampon' would enable fair distribution of the catch (Somayaji and Coelho, 2017). The Ramponkars fish in shallow waters within a distance of two kilometres from the shore, usually after low tide (D'cruz and Raikar, 2004). The catch is divided according to the percentage of ownership of the giant net among owners and helpers (Newman et. al 2001). It is speculated that the quantity of the catch previously was so abundant that the excess, especially prawns, would be used as manure for coconut plantations (Somayaji and Coelho, 2017).

There are documented accounts of the high level of influence of the Portuguese government on traditional fishing livelihoods and coastal societies in colonial Goa (Somayaji and Coelho, 2017). The prohibition of commercial fishing vessels like trawlers and purse seiners within five fathoms (30 ft.) of the seaward shore was established through several laws by the Portuguese government (Somayaji and Coelho, 2017). Fishermen narrate that a distance measuring 'ten bamboo sticks' was reserved on the beach for fisheries-allied activities like net mending, housing, fish drying and boat maintenance for the Ramponkars (Somayaji and Coelho, 2017). The Portuguese strictly regulated the mesh size of the net to one anna coin (one sixteenth of a rupee coin) and prohibited the use of nylon nets. The violations of these specifications and rules led to immediate burning of the nets (Somayaji and Coelho, 2017).

\section{Present status quo and policy protection of the Kolis and Ramponkars in India}

Coasts have been historically referred to as 'commons' — lands without private or state ownership and governed through traditional law (Siddharth Chakravarthy, 2020). The access to the coast is vital (Siddharth Chakravarthy, 2020) as it provides for the sustenance of social, cultural and economic means for communities like the Kolis and Ramponkars. These societies are often misrepresented or under-represented in the state development planning reports (Sarita Fernandes, 2020) and public development projects under various political and private market pressures of infrastructure (Shweta Wagh, 2019), tourism (Paul Routledge, 2001), mining (Antonio Mascarenhas, 1999) and so on. 
Coastal societies like the Kolis, Ramponkars and others alongside India's coastline are collectively recognised under the coastal regulation zone notifications of 2011 as 'traditional fishing villages' and earmarked for special provisions and restrictions in housing and fisheries related facilities like net mending yards and boat parking (Coastal regulation zone notifications, 2011; Sarita Fernandes, 2019). It also mentions a no development zone (NDZ) with policy considerations and restrictions on the floor space index (FSI) for housing within the fishing villages due to their proximity to the intertidal zones of the coast (Coastal regulation zone notifications, 2011).

The provisions under the coastal regulation zone notifications for traditional coastal societies are based solely upon their economic dependence on fishing as a prominent factor in policy. The indigeneity or cultural construct as well as considerations of the traditional laws on coastal commons have not been considered. This has presently led to the fragmentation of these commons among several indigenous and non-indigenous actors, prominently being a result of the private sector infrastructure and tourism boom after the Liberalisation, Privatisation and Globalisation movement in India (K.M Gopakumar et al. 2020). Unlike the tribals, who are recognised under several state and central forest laws and provisions, indigenous coastal communities like the Kolis and Ramponkars have low levels of state and central policy protection with a limited database on their history, socio-cultural and bio-cultural relevance to the coast. The incentivization of large scale fishing like trawling and purse seining has presently proliferated the monopoly of the fisheries sector to market pressures (Somayaji and Coelho, 2017; Antonio Mascarenhas, 1999).

Literature on the role of indigenous knowledge in the adaptation of pressing environmental issues like climate change has been recognised as essential; with scientific knowledge (and the community) acknowledging it does not have all the answers to tackle these emerging issues. (UNESCO, 2012). The data and scholarship for Indian coastal societies, especially for indigenous groups like the Kolis and Ramponkars stands on the premise of opportunity into sustainable development and collective policy mitigation that can have multi-sectoral benefits to building climate risk resilience and adaptation.

\section{Challenges of coastal societies}


The challenges faced by the Kolis and Ramponkars in Maharashtra and Goa are constructed and presented based on the present academic literature, written official demands from community representatives, field notes, prominent protests and community led public interest litigations.

Despite numerous studies on different societies in India, the coastal population of India's west and east coast have been poorly studied (L.S Sanghvi, 1977). Coastal communities like the Ramponkars and Kolis have led several community based demands over the last five decades regarding India's enforced modernization of fisheries (Somayaji and Coelho, 2017) which has witnessed a cascading impact on non-fishing coastal livelihoods and eco-sensitive habitats. The paradox of contemporary resistance according to Castells (1997) is a proliferation of local politics structured by global processes (Paul Routledge, 2001). Resistance that arises from territorial identity are often defensive and reactive focusing on the conservation of people's or community spaces and the immediate environment (Paul Routledge, 2001; Castells, 1997). In the last twenty years, several coastal stretches which once displayed vast wilderness and healthy shores are now reduced to haphazardly developed stretches (Alvares, 1993 ; Antonio Mascarenhas, 1993; Sawkar et al. 1993). A prominent result of this coastal concrete built up with low policy pathways and scientific grounding guiding the development (Antonio Mascarenhas, 1999) is the severe natural erosion of several coastal zones in India (Antonio Mascarenhas, 1999; Sarita Fernandes, 2020).

The projection of modernity's vantage point on indigenous coastal societies (Somayaji and Coelho, 2017) can be witnessed in the challenges raised by demands from the Ramponkars (Somayaji and Coelho, 2017) and Kolis (Punekar, 1959; Pranita et al. 2019).

\section{Neoliberalism and Indigenous representation}

Socio-natures are established relationships between human and non-human interactions. (Isabel Altamirano-Jimènez, 2013) These relationships and interactions are selectively subsumed within the process of neoliberalisation (Nast, 2006; Bakker, 2010; Isabel Altamirano-Jimènez, 2013). In the demands for recognition, territory and self-determination, indigenous communities have articulated structures and meanings of indigeneity and cultural difference to create (or maintain) distinct identities to state and other transnational actors (Isabel Altamirano-Jimènez, 2013). 
The state failure in providing policy support and resources from repeated demands, to sustain requisites in coastal commons of the Ramponkars and Kolis have resulted in them moving away or poorly sustaining their occupation and livelihoods (Heraldo, 2016). The demands from both these societies have ranged from stakeholder indigenous representation (Simantini Dey, 2019), policy support, considerations in spatial planning (Paul Routledge, 2001 ), issues emanating from climate change risks like flooding (Sibananda Senapati, 2016) and reduced fish catch (Simantini Dey, 2019). Monetary compensation measures offered by the states and centre for coastal land use of fishing villages and reclamation of the intertidal coastal commons have been repeatedly rejected by both these communities citing intergenerational equity (Sarita Fernandes, 2019).

The neoliberalism wave into commercial fishing (trawling, purse seining), port development (George Mendonca, 2021), coastal tourism (Paul Routledge, 2001) and infrastructure based employment has created silos within these societies with the next indigenous generation moving towards these sectors (Jesyl Fernandez, 2018 ) and abandoning the society's idea of indigeneity.

Several economic and social indicators suggest the alarming rate of India's absolute poverty and the impact of neoliberal policies on poverty (Patnaik, 2007). The contradiction with spatial planning in neoliberalism and indigenous understanding of commons (Isabel Altamirano-Jimènez, 2013), especially for livelihoods in terms of the coastal societies (Shweta Wagh et. al 2019) is clearly drawn, especially from repeated demands as received from the Kolis and Ramponkars in terms of fair coastal commons' governance and policy issues (Ramdas Janardan Koli vs The State Of Maharashtra, 2014).

\section{Blue to brown economy transition?}

Indian coastal waters are extremely biodiverse ecosystems which include mangrove forests and coral reefs contributing to the geomorphological, climatic (Balakrishna, 2012), economic and cultural attributions (Sarita Fernandes, 2019). Brown (economy) growth describes economic development that relies heavily on fossil fuels and does not take into consideration the ill-effects that the economic production and consumption will have on the environment (World Bank, 2013). In 2005, Dr. M.S Swaminathan constituted a report that formed the basis of the coastal regulation 
zone notifications 2011 that mentioned 'livelihood security by means of coastal conservation' and 'sustainable development' based on scientific principles of all coastal stretches' (Sundararaju, 2019; Ministry of Environment and Forests, 2005). The annexure of this clause was dissolved by the recent coastal regulation zone notifications of 2019 which skipped the provisions of coastal societies that the 2011 notification granted to coastal societies. (Sarita Fernandes, 2020). India has no roadmap for phasing out coal dependence and ensuring transitions for her communities under G20 and the Paris Agreement goals. (Coal India, 2018). Contrary to the G20 and Paris Agreement goals, India's recent plans to liberalise new investments into coal mines (Dutta, 2020, Bullard, 2020) backtracks the transition from brown to blue and green economy (Climate Transparency Report, 2020). The National Adaptation strategies for i. Coastal areas and Fishing ii. Infrastructure iii. Tourism iv. Urbanisation and v. Biodiversity is ranked 'very low' as per the 2020 Climate Transparency report on India.

A case in point is Sagarmala - India's port infrastructure project under the blue economy goals to create a coast based industrial model (Alagar et al., 2020) by developing over 397 ports (Report on government imperatives including financial plans, Ministry of Shipping, 2016) out of which only 6 ports are earmarked for development as greenfield ports (Report on government imperatives including financial plans, Ministry of Shipping, 2016). Coastal community development under Sagarmala (Alagar et al., 2020) aims to train and skill develop coastal communities for jobs related to ports, maritime industrial clusters and also mentions grants for fishermen social welfare to provide opportunities for coastal societies outside of fisheries. (Report on government imperatives including financial plans, Ministry of Shipping, 2016). The project is a case in point of India's low policy and demographic understanding of its coastal societies, especially indigenous communities like the Kolis and Ramponkars that sustain their livelihoods and entire social and cultural construct based on indigeneity over economic growth and livelihood reform.

\section{Climate Change}

In a 2016 survey with the Kolis, 52\% of the fishers were aware about climate change and $49 \%$ fishers perceived a very high change in rainfall patterns due to climate change (Senapati 2016). Kolis across Mumbai and Maharashtra have a synonymous story on the impact of climate related disasters to their villages, rise in temperatures and pollution on the vanishing and shrinking catch 
of fish (Subuhi Jiwani-UNDP India 2019). The changes in movement of fish like sardines and pomfrets have compromised the sustenance of local catch among traditional fisher societies (Subuhi Jiwani-UNDP India 2019) which now looks towards commercial fisheries as the only sustaining option to maintain indigeneity.

India has the second largest population in the world, out of which sixty-three million people are located in the Low Elevation Coastal Zone (LECZ) (Gordon Mcgranahan 2007). An estimated forty lakh people from traditional fishing communities live along the coastline and are dependent on near-shore fisheries for their livelihood and sustenance (Sekhsaria 2020). The Indian coastline is one of the most vulnerable, risk prone and densely populated regions in the world (Youdon 2020). Climate change induced sea level rise is beyond coastal inundation and erosion (TERI 1998) and now transcends into high risk of displacement for coastal communities and Small Island populations (Centre for Education and Documentation 2010).

India is ranked susceptible to 'very high' impacts of climate change, even if the temperature increase is maintained at 1.5 degree Celsius (India Climate Transparency Report 2020). About 2925 fatalities and \$14 billion U.S dollars' worth of losses are recorded yearly on an average due to extreme weather events (German Watch 2019). The country is extremely vulnerable to climate change and adaptation measures (India Climate Transparency Report 2020) in terms of investment and innovations for readiness are urgently needed (Andrijevic 2020).

\section{Discussion}

The perspectives of the Kolis and Ramponkars present an understanding of the societal construct around coastal hegemony. The challenges present the silos that require collaborative solutions of technology and adaptation frameworks for indigeneity through existing frameworks of policy and available resources in India. Alongside, the present opportunities and scholarship in studying the Kolis and Rampokars with regard to cultural and indigenous knowledge, their sustenance 


\section{Diagram 2.1: Convergence of challenges and present opportunities}

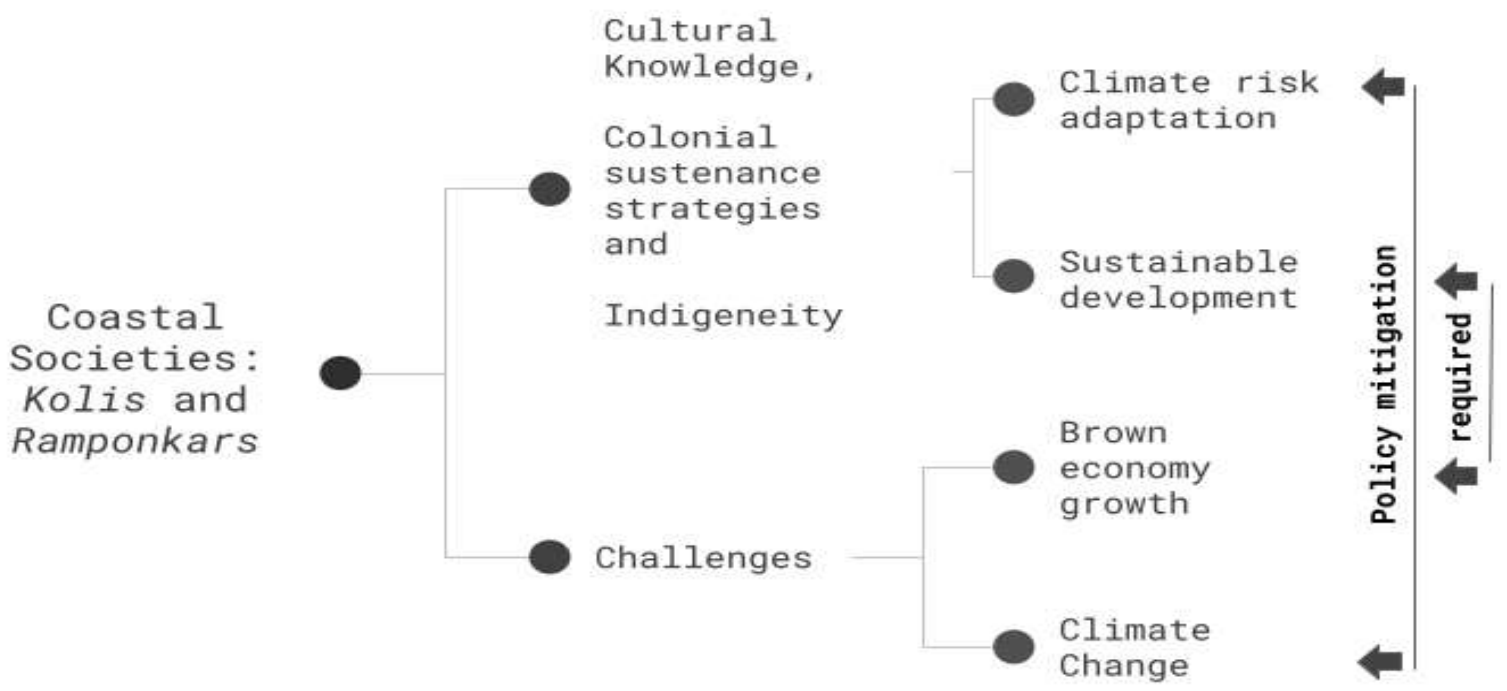

Source: Author

with two different and competing colonisers, the existing policy considerations that provide the community's access to the coast and the co-operative-coastal commons approach of use of resources could provide several new options. Exploring the community constructs could also provide a wider gambit in finding solutions to climate risk adaptation and a better understanding of sustainable development. However, policy mitigation and subsequent implementation as a supporting catalyst would be required by state and non-state actors. These can be analysed within existing policy loopholes or the missing state interventions from challenges.

\section{Conclusion}

The discussion that is represented in diagram 2.1 - 'Convergence of challenges and present opportunities' depicts the capacity and opportunities of the communities in indigenous knowledge on climate risk adaptation that could provide solutions for the entire rural-urban construct they influence. Similarly, the options and pathway models in deflating India's brown economy growth and transitioning towards the blue economy could be studied if adequate representation from such societies is presented in public policy. India has an existing ecosystem of healthy and biodiverse 
coastlines and the influence, linkage and presence of indigenous societies like the Kolis and Ramponkars on such ecologically high value ecosystems could be studied further to understand any patterns and solutions emanating from them. This also provides opportunities to establish a local and national subset in understanding the blue economy and India's sustainable development opportunities and challenges in the transition.

\section{References:}

1. The Ocean Conference - United Nations. (2017). Factsheet: People and Oceans'. United Nations.

2. Youdon, C. (2020). Impact of climate change on coastal cities: an 'integrated adaptation' approach part I. National Maritime Foundation. New Delhi https://maritimeindia.org/impact-ofclimate-change-on-coastal-cities-an-integrated-adaptation-approach-part-i/ accessed 04 March 2021

3. Hein, C. (2019). Adaptive Strategies for Water Heritage: Past, Present and Future (1st ed. 2020 ed.) Springer.

4. Egberts, L. (2021). Heritage in European Coastal Landscapes-Four Reasons for Interregional Knowledge Exchange. In Hein, C (Ed.), Adaptive Strategies for Water Heritage Past, Present and Future (p. 341). Springer Publishing. https://doi.org/10.1007/978-3-030-00268-8

5. Sawkar, K, Mascarenhas, A, Noronha, L, \& Chauhan. (1997). Tourism and environment: Issues of concern in the coastal zone of Goa. In: Tourism and environment case studies on Goa, India and the Maldives. Economic Development Institute of the World Bank, Washington.

6. Antonio M. (1999). Some observations on the state of the coastal environment of goa, west coast of India (Geology Division ed.). National Institute of Oceanography, Dona Paula.

7. Somayaji, Ganesha \& Coelho, Joanna P. (2017). Fissures of a Blue Revolution: The Ramponkars' Response to Mechanised Fishing in Goa. SAGE Publications. https://doi.org/10.1177/0049085717696392

8. Johnson, Marcha \& Bailey, Amanda. (2016). Coastal Change, Ocean Conservation and Resilient Communities. Springer International Publishing Switzerland, 1-4. https://doi.org/10.1007/978-3-319-41914-5

9. World Bank and United Nations Department of Economic and Social Affairs. (2017). The Potential of the Blue Economy: Increasing Long-term Benefits of the Sustainable Use of Marine Resources for Small Island Developing States and Coastal Least Developed Countries. World Bank, Washington DC. https://www.worldbank.org 
10. Harff, Jan., Soomere, Tarmo \& Zhang, Hua. (2019). Coast and society. Journal of Coastal Conservation Special Issue, 713-716. https://link.springer.com/content/pdf/10.1007/s11852-01900705-y.pdf

11. UNESCO. (2020, January 8). Sustainable development and environmental change. https://en.unesco.org/indigenous-peoples/sustainabledevelopment\#:\%7E:text=Sustainable\%20development\%20and\%20environmental\%20change,In $\% 20$ the $\% 20$ face \& text $=$ The $\% 20$ knowledge $\% 20$ of\%20indigenous $\% 20$ peoples, and $\% 20$ meaning ful\%20action\%20world\%2Dwide accessed on 18 March 2021

12. Yesudas, Lisba \& Jament, Johnson (2019, December 19). Marine Biodiversity and Cultural Diversity: The Coastal Communities of Trivandrum, Kerala, India. Landscape Magazine. https://medium.com/langscape-magazine/marine-biodiversity-and-cultural-diversity-in-thecoastal-communities-of-trivandrum-kerala-india-868675899061 accessed on 18 March 2021

13. Sanghvi, L. D. (1977). Nature of Genetic Variation in the People of Western India: Vol. Cancer Research Institute. Tata Memorial Centre. Bombay

14. Chhabria, S. (2018). The Aboriginal Alibi: Governing Dispossession in Colonial Bombay. Comparative Studies in Society and History, 60(4), 1096-1126. https://doi.org/10.1017/s0010417518000397

15. Hasan, Arif. (2002). The Unplanned Revolution: Observations on the Process of SocioEconomic Changes in Pakistan. Karachi City Press.

16. Harad, Pranita a. \& Joglekar. P.P. (2017). A study of fish symbolism in the life of the son koli community of Mumbai (Vol. 77). Bulletin of the Deccan College, Pune

17. Punekar, V. B. (1959). The Son Kolis of Bombay. Bombay: Popular Book Depot

18. Roy, Shibani. (1983). Koli Culture: A Profile of the Culture of Talpad Vistar. Cosmo, New Delhi.

19. Perlin, F. (1983). Proto-Industrialization and Pre-Colonial South Asia. Past and Present, 98(1), 30-95. https://doi.org/10.1093/past/98.1.30

20. Routledge, P. (2001). "Selling the rain", resisting the sale: Resistant identities and the conflict over tourism in Goa. Social \& Cultural Geography, 2(2), 221-240. https://doi.org/10.1080/14649360120047823

21. Ecoforum. (1995). Fish, Curry and Rice: A Citizen's Report on the Goan Environment. Other India Press. Pune.

22. Shirodkar, P.P. and Mandal, H.K. (1993) People of India: Goa, volume 21. Popular Prakashan. Bombay.

23. Alvares, C. (1993). Fish, Curry and Rice: A Citizen's Report on the State of the Goan Environment. Ecoforum, Goa, pp. 260.

24. Lobo, Aaron. (2020). Shevtto: The Story of Goa's Unlikely State Fish. https://www.goya.in/blog/shvetto-the-tale-of-goas-unlikely-state-fish accessed 04 March 2021

25. D’Cruz, S., \& Raikar, A.V. (2004). Ramponkars in Goa: Between modernisation, government and the deep blue sea. Economic \& Political Weekly, 39(20), 15-21 May, 2048-2050. 
26. Newman, R. (2001). Of umbrellas, goddesses and dreams: Essays on Goan culture and society. Mapusa: The Other India Press. Goa

27. Wagh, Shweta \& Indorewala, Hussain (2019, March 7). As Mumbai's Coastal Reclamation Begins, Artisan Fishers Fight for Their Livelihood. Https://Thewire.in/Rights/Mumbai-CoastalReclamation-Artisan-Fishers-Livelihood. https://thewire.in/rights/mumbai-coastal-reclamationartisan-fishers-livelihood

28. Fernandes, Sarita. (2020, May 1). Their Village Sealed Off, Worli's Small-Scale Fishers Lose Livelihood. Https://Thewire.in/Rights/Worli-Small-Scale-Fishers-Covid-19. https://thewire.in/rights/worli-small-scale-fishers-covid-19

29. Chatterjee, B. (2020, June 8). CRZ 2019 looks at coast as an industry, mulls real estate, port development: Experts. https://www.hindustantimes.com/mumbai-news/crz-2019-looks-atcoast-as-an-industry-mulls-real-estate-port-development-experts/story-

glsDDM3VvMK6hz388303fO.html accessed 19 March 2021

30. Sengupta, R. G. K. M. (2020, April 15). Economic liberalisation and its faults. https://www.thehindu.com/opinion/op-ed/economic-liberalisation-and-itsfaults/article31341924.ece accessed 24 March 2021

31. Castells, M. (1997) The Power of Identity. Blackwell. Oxford

32. Herald, T. (2016, May 10). Traditional fishermen to 'quit' occupation.. https://www.heraldgoa.in/Goa/Traditional-fishermen-to-\%E2\%80\%98quit\%E2\%80\%99occupation/101850 accessed 24 March 2021

33. Kapoor D. (2019). 'Govt Doesn't Do Anything But...'?: What's Making Mumbai's Koli Women Vote Today Despite Skepticism' https://www.news18.com/news/india/govt-doesnt-doanything-but-whats-making-mumbais-koli-women-vote-today-despite-skepticism-2120749.html accessed 24 March 2021

34. Fernandes, Sarita. (2019, July 16). Mumbai Coastal Road: Pathway to ruin. Retrieved from: https://www.downtoearth.org.in/blog/environment/mumbai-coastal-road-pathway-to-ruin65665 accessed 04 March 2021

35. Patnaik, Utsa (2007, July 28). Neoliberalism and Rural Poverty in India : https://www.epw.in/journal/2007/30/aspects-poverty-and-employment-specials/neoliberalismand-rural-poverty-india.html accessed 18 March 2021

36. Pisupati, B. (2012) 'Marine Biodiversity ' Zoological survey of India, Kolkata (1-164)

37. World Bank. (2013, June 25). From Brown Growth to Green: the Economic Benefits of Climate Action. https://www.worldbank.org/en/news/feature/2013/06/25/growing-green-europeand-central-asia accessed 19 March 2021

38. Ministry of Environment and Forests. (2005, February). Report of the committee chaired by Prof. M. S. Swaminathan to review the coastal regulation zone notification 1991. New Delhi.

39. Climate Transparency and TERI. (2020). India: CLIMATE TRANSPARENCY REPORT.https://www.climate-transparency.org/wp-content/uploads/2020/11/India-CT-2020.pdf accessed 24 March 2021 
40. Chakravarty S. (2020). The Research Collective - Programme for Social Action (PSA). Occupation of the coast - Blue economy in India. https://in.boell.org/en/2018/04/26/occupationcoast-blue-economy-india accessed 19 March 2021

41. Alagar, G. Premkumar, L. Ishita (2020). The Research Collective - Programme for Social Action (PSA). Occupation of the coast - Blue economy in India. https://in.boell.org/en/2018/04/26/occupation-coast-blue-economy-india accessed 19 March 2021

42. Jiwani, Subuhi. (2019, December 23). The shrinking pomfret of suburban Mumbai. UNDP. India. $\quad$ https://www.in.undp.org/content/india/en/home/climate-and-disasterreslience/successstories/pari-undp-series/pomfret-Mumbai.html accessed 04 March 2021

43. Senapati, Sibananda. (2016). 'Climate change and vulnerability of fishing communities' Global Fish Adapt Conference. Bangkok

44. Sekhsaria, P. (2017, November 11). Many shades of a blue economy: Sagarmala project. The Hindu. https://www.thehindu.com/sci-tech/energy-and-environment/many-shades-of-a-blueeconomy-sagarmala-project/article20104312.ece accessed 29 March 2021

45. CED. (2020, September 1). Coastal communities in India bear the brunt of climate change. Centre for Education and Documentation (CED). https://www.ritimo.org/Centre-for-Educationand-Documentation accessed 19 March 2021

46. Fernandez, J. (2018, October 8). Arambol celebrates the Ramponkaranche Ani Voddekaranchem Fest. ItsGoa. https://itsgoa.com/arambol-celebrates-the-ramponkaranche-anivoddekaranchem-fest/ accessed 24 March 2021

47. Ministry of Shipping. (2016). Report on government imperatives including financial plans SAGARMALA.

http://sagarmala.gov.in/sites/default/files/7298227416DraftReportonImperativesSagarmala.pdf accessed on 29 March 2021

48. Isabel, Altamirano-Jimènez. (2013). Indigenous Encounters with Neoliberalism: Place, Women, and the Environment in Canada and Mexico. UBC PRESS.

49. Subrahmanyam, S., \& Bayly, C. A. (1988). Portfolio capitalists and the political economy of early modern India. The Indian Economic \& Social History Review, 25(4), 401-424. https://doi.org/10.1177/001946468802500402

50. Balakrishna, Pisupati (2012). Marine Biodiversity, Zoological survey of India, Kolkata, 13.

51. Sundararaju, V (2019). Why we need a coastal zone protection act, Down To Earth, Retrieved from: https://www.downtoearth.org.in/blog/environment/why-we-need-a-coastal-zoneprotection-act-62876 accessed on 14 March 2021

52. Mcgranahan, Gordon \& Balk, Deborah \& Anderson, Bridget. (2007). The Rising Tide: Assessing the Risks of Climate Change and Human Settlements in Low Elevation Coastal Zones. Environment and Urbanization - Environ Urban (SAGE Publications). Pp 17-19. https://doi.org/10.1177/0956247807076960 
53. Climate Transparency \& TERI (2020). India Climate Transparency Report, Retrieved from: $\quad$ https://www.climate-transparency.org/wp-content/uploads/2020/11/India-CT-2020WEB.pdf accessed 24 March 2021

54. German watch. (2019) Global Climate Risk Index 2020. Who Suffers Most from Extreme Weather Events? Bonn, Germany. Retrieved from:

http://www.germanwatch.org/ accessed 24 March 2021

55. Andrijevic, M., Crespo Cuaresma, J., Muttarak, R. et al. Governance in socioeconomic pathways and its role for future adaptive capacity. Nat Sustain 3, 35-41 (2020). https://doi.org/10.1038/s41893-019-0405-0 